\title{
Enige toepassingen van de leer van de marktvormen
}

\author{
door \\ Prof, Dr Th. L. M. THURLINGS
}

\begin{abstract}
R E D E
uitgesproken bij de aanvaarding van het ambt van gewoon hoogleraax aan de Landbouwhogeschool te Wageningen op 28 Maart 1950
\end{abstract}

DE ERVEN F. BOHN N.V. - HAARLEM 
Overdrulk De Eçonomist 1950 
Mijne Heren Curatoren

Mijne Heren Hoogleraren

Mevrouw en Mijne Heren Lectoren, Docenten, Wetenschappelijke Medewerkers, Assistenten, Dames en Heren Studenten en Gij allen voorts, die deze plechtigheid met $U_{w}$ aanwezigheid vereert.

\section{Zeer gewaardeerde Toehoorders,}

Het was in de laatste decennia der achttiende eeuw, dat de economische wetenschap zich als zodanig begon af te tekenen uit de veelheid van beschouwingen van sociaal-ethische en van practische aard, die zich met economische problemen bezig hielden. Twee gebeurtenissen, de ene in het staatkundig-sociale vlak, de andere in het technisch- economisch- sociale gebied, waren het, die in deze tijd zich voordeden en aparte hoofdstukken in de geschiedenisboeken zijn gaan vormen. De ene was de Franse revolutie, de andere het mechanisatie- en industrialisatieproces, dat in Engeland inzette en vele decennia later als Industriële Revolutie is bestempeld. Hoe verscheiden van aard en oorsprong beide gebeurtenissen ook waren, $\mathrm{zij}$ stemden op één punt overeen, n.l. dat $\mathrm{zij}$ beide tot gevolg hadden een doorbreking van een systeem van, in Engeland zowel als in Frankrijk, voor een aanmerkelijk deel van de overheid uitgaande, geleide economie. Verzet in Frankrijk tegen de misbruiken en misstanden vooral in sociaal opzicht aan het oude regiem verbonden, verzet in Engeland tegen de beklemming, welke het oude net van verordeningen op het naar nieuwe technieken grijpende bedrijfsleven uitoefende, bracht in beide landen het verlangen naar vrijheid op economisch gebied voort.

Het ligt niet in onze bedoeling materialistische geschiedbeschrijving te bedrijven. Geenszins ontkennen wij de krachtige invloed, welke uit de wereld van het filosofische denken in de bovenvermelde richting werd uitgeoefend, doch wij willen slechts de aandacht vragen voor het verschijnsel, dat rondom het jaar 1800 de drang bestond naar een vrije economie. Eeuwenlang had de piloot zichtbaar in de stuurstoel gezeten, men was hem en zijn verrichtingen moede, en men stelde zijn hoop op een onzichtbare automatische piloot, te weten de werking van de vrije concurrentie. Uit de sfeer der natuurrechts-filosofie was het vertrouwen in deze automatische piloot reeds gewekt. De economische wetenschap, die zich uiteraard 
en door de behoeften van haar geboortemilieu ging bezighouden met de vraag naar de resultante der individuele disposities, sprak met zoveel woorden haar vertrouwen in het goede functioneren van de concurrentie uit. Vrije concurrentie, zo luidde haar opvatting, zou er voor zorgen, dat de voortbrenging met minimale kosten zou geschieden en dat de verkoopprijzen met de kostprijzen zouden overeenstemmen. Een verstoring van dit optimistische beeld zou slechts te duchten zijn, waar natuur of wetgeving aanleiding mochten geven tot het ontstaan van monopolies.

Aldus werd een prijstheorie opgebouwd op een tweetal eenvoudige marktsituaties, die van de volledige mededinging en die van het monopolie. Tal van complicaties, welke zich bij de confrontatie van theorie en realiteit voordeden, werden als fricties, welke door de tijd wel zouden worden uitgewist, terzijde geschoven.

Dit theoretische apparaat, waarvan een aantal doffe plekken in de loop der jaren werd opgepoetst, is naar moderne opvatting geenszins zonder betekenis. Tinbergen in zijn boek „Beperkte Concurrentie" zegt er over: "In de negentiende eeuw heeft men de ook heden nog grotendeels aanvaarde economische theorie opgebouwd op de hypothese van de vrije concurrentie, die bij benadering voor grote delen van het economisch leven als juist mag worden aangenomen. Men is er in geslaagd een elegant en gemakkelijk hanteerbaar theoretisch apparaat te scheppen, waarmede men tal van pioblemen heeft kunnen ontleden en oplossen" 1 ).

Ook van Stackelberg, nadat hij de hoop op een "geschlossenen allgemeinen Preistheorie" als een illusie ter zijde geschoven heeft erkent: „ausserdem behält die Theorie der Preişbildung bei volständiger Konkurrenz ihre Bedeutung uberall dort, wo es auf die Gewinnung einer Vergleichsbasis oder nur auf die allgemeinen Tendenzen der Preisbewegung, nicht auf ihre Feinheiten ankommt" 2 ).

Deze erkenning houdt echter geen verwerping in van een verfijning, waar daaraan behoefte mocht bestaan. Die behoefte heeft zich rondom 1930 doen gevoelen, deels in de geest der beoefenaars van de economische wetenschap uit een innerlijke drang naar perfectie, deels doordat de economische politiek om bijstand vroeg en de beoefenaars der wetenschap voor gedetailleerdere problemen

1) J. Tinbergen, Beperkte concurrentie, Leiden 1946, blz. 11.

2) H. v. Stackelberg, Grundlagen der theoretischen Volkswirtschaftstehre, Bern 1948, S. 248. 
stelde dan waarop het traditionele apparaat der economische theorie was ingesteld.

In deze tijd is de leer van de marktvormen ontwikkeld, die het stramien vormt, waarop de moderne prijstheorie is geborduurd.

Over de inhoud van het begrip marktvorm bestaat tussen de diverse schrijvers nog weinig eenstemmigheid. Het komt ons dienstig voor om, min of meer in navolging van Tinbergen, bij de marktvormen de nadruk te leggen op zekere objectieve omstandigheden, waaronder de ruil plaats vindt. Als eerste en zeer belangrijke omstandigheid zouden wij dan willen stellen, het aandeel, dat ieder der marktpartijen heeft aan de omgezette hoeveelheid. Aangenomen - welk punt aanstonds aan de orde zal worden gesteld homogeniteit van de waar, kan men spreken van vrije mededinging als het aantal marktpartijen zeer groot is, zodanig dat de afzonderlijke verkoper geen invloed heeft op de marktprijs, van oligopolie, als het aantal aanbieders gering is, en van monopolie indien er slechts één aanbieder in de markt is. Hierbij werd stilzwijgend aangenomen, dat het aantal partijen aan de vraagzijde zeer groot is. Het is echter allerminst nodig, zulks te veronderstellen. Neemt men ook aan de vraagzijde der driedeling ,vele, weinige en één marktpartij" in het schema op, dan komt men tot een negental marktvormen, variërende van wederkerig monopolie tot vrije mededinging.

$W_{i j}$ vermeldden in het voorafgaande reeds het element homogeniteit van de waar. Hiermede wordt bedoeld, dat er noch bij, de vragers noch bij de aanbieders om welk reden dan ook enige voorkeur bestaat voor de ene wederpartij boven de andere. Bestaat er wel voorkeur, doch is de prijssamenhang tussen de varianten nauw, dan beschouwt men vaak de bundel van in prijs nauw met elkaar samenhangende artikelen als één goed, dat dan als een gedifferentiëerde waar wordt aangeduid. De marktvormen, betrekking hebbend op deze gedifferentiëerde waar, worden van die voor de homogene waar onderscheiden door de toevoeging "monopolistisch".

Voor de prijsvorming zijn voorts nog tal van andere omstandigheden van grote invloed. Van veel betekenis is de vraag of de markt open dan wel gesloten is, waarbij openheid voor een monopolistische markt slechts kan betekenen de mogelijkheid om een nabij vervangingsmiddel in het leven te roepen. Voor zo ver de markt dan al van rechtswege openstaat, is van belang, of nieuwe vestiging al dan niet te kampen zal krijgen met gebrekkige mobiliteit van productiefactoren. Kennis van de marktomstandigheden is een volgend 
belangrijk punt. Vaak wordt in de theorie expliciet transparantie van de markt aangenomen, impliciet gebeurt zulks o.i. telkens wanneer volledige homogeniteit van de waar wordt verondersteld.

Neemt men de hier bedoelde omstandigheden van vrijheid van vestiging en van volkomen markttransparantie aan, dan kenmerkt men de marktvorm vaak door de toevoeging "volledig", "volkomen" of "perfect" 3 ).

Langs deze lijnen heeft de moderne theorie de prijsleer ontwikkeld, daarbij gebruik makend van een bonte veelheid van premissen, zoals ten aanzien van de transparantie der markt, de mobiliteit der productiefactoren, en de gedragsijn van aanbieders en vragers. Het resultaat van deze wetenschappelijke arbeid was, dat de optimistische conclusies ten aanzien van de selecterende en organiserende werking van de concurrentie, die reeds lang door de feiten werden weersproken, nu ook op grond van wetenschappelijke beschouwingen werden weerlegd. Voorts bracht hij het inzicht, dat voor belangrijke delen van het economische leven, waarin oligopolistische situaties heersen, niet op grond van theoretische betogen tot een eenvoudige en op de werkelijkheid toepasselijke conclusie is te geraken, zo zeer zelfs dat bijv. door Rothschild in zijn artikel „Price Theory and Oligopoly" (Economic Journal 1947) de opvatting werd verkondigd, dat het beter ware het construeren van allerlei gekunstelde theorieën maar te staken en een empirische weg te gaan bewandelen.

Dit alles neemt niet weg, dat voor bepaalde problemen de theoretische conclusies zekere bruikbaarheid bezitten en dat, gelijk Nicholls het in zijn boek "Imperfect Competition Within Agricultural Industries" uitdrukt, de theorie voor oligopolistische markten toch altijd het voordeel biedt „to sharpen ... thinking and tools of analysis in order to do a better job of empirical work" ").

Van deze leer der marktvormen nu willen wij een tweetal toepassingen in ogenschouw nemen. De eerste heeft betrekking op het verschijnsel dat sommige goederengroepen wel en andere niet op markten, beurzen of veilingen worden verhandeld, de andere betreft de hoge kosten van de distributie, waarbij wij onze gedachten willen bepalen tot de detailhandel in groente en fruit. Zo men wil zou men kunnen zeggen, dat het eerste verschijnsel een structureel, het andere

s) Cf. A. L. Meyers, Elements of modern economics, New York 1946, p. 93.

4) W. H. Nicholls, Imperfect Competition Within Agricultural Industries, lowa State College Press, 1947, p. 165. 
een prijsvormingsaspect betreft, mits men dan maar voor ogen houdt, dat economische structuur en economisch proces geen van elkaar onafhankelijke verschijnselen zijn, doch dat tussen beide een wederkerige afhankelijkheid bestaat.

\section{Het vraagstuk van het marktwezen.}

In de theoretische economie wordt het begrip markt veelvuldig gebruikt, doch vrijwel steeds wordt geheel en al in het midden gelaten op welke wijze de ontmoeting van vraag en aanbod, die de inhoud vormt van het begrip markt, zich voltrekt.

Het is dan ook niet te verwonderen, dat de studie van deze op zich zelf alleszins belangwekkende vraagstukken in het verleden werd ter hand genomen door de zogenaamd bedrijfseconomisch georiënteerden, diegenen die zich meer in het bijzonder met de concrete dingen des dagelijksen levens bezig hielden: In het onderdeel der economische wetenschap, dat met de misleidende naam van "Organisatie en Techniek van de Handel" wordt aangeduid, werd aldus deze reeks van vraagstukken aangepakt.

In ons land werd een aanzienlijk deel van deze arbeid verricht door wijlen Prof. Dr. N. J. Polak, Hoogleraar te Rotterdam. Hij was het, die in 1924 de gelukkige formulering bracht, welke voor jaren de inzichten van zeer velen der Nederlandse economen zou bepalen.

In dat jaar 1924 immers hield Prof. Polak een diesrede, getiteld „De Taak van den Tusschenhandel" waarin de geleerde spreker onderzocht onder welke voorwaarden in het geheel der maatschappelijke arbeidsverdeling een plaats, een economische taak, is weggelegd voor die bedrijven, welke wij gewend zijn als handelsbedrijven aan te duiden. Hij kwam toen tot de conclusie, dat deze voorwaarden - zoals hij het in 1937 in zijn rede „Distributievraagstukken" zelf samenvatte - zijn: „Dat de meest economische bedrijfsgrootte ter vervulling van de functies bereikt wordt op een schaal, die boven de behoefte van iederen gebruiker van die diensten uitgaat, en/of dat de gezamenlijke behoeften aan die diensten van cen aantal gebruikers gelijkmatiger zijn dan de behoefte van elk dezer gebruikers afzonderlijk".

De laatstomschreven voorwaarde, door Prof. Polak gelijkmatigheidstendens gedoopt, werd door hem ook gesteld voor het verschijnsel der geografische concentratie van het houden van de voorraad, en voor de geografische concentratie van kopers en verkopers, t.w. op die punten, waar een gelijkmatiger vraag en aanbod zich 
openbaart dan in enig gebied buiten deze trefpunten, waardoor enerzijds met een kleinere voorraad een zelfde effect, anderzijds met minder moeite een gelijk commerciëel resultaat kan worden verkregen.

Toen spreker vervolgens deze theorieën wilde gaan toepassen op de werkelijkheid van $z$ ijn tijd, zag hij zich genoodzaakt een onderscheid te maken tussen "de handel in massagoederen, veelal producten van mijnbouw en van agrarische bedrijven ... en die in speciale artikelen van industriële oorsprong". „De massagoederen (aldus (spreker) worden door den collecterenden handel of door de producenten zelf naar de exportmarkt gebracht en daar verkocht".

„Daarentegen ontbreken bij den handel in industriëele artikelen zoowel de collecteerende handel als de markt, het laatste woord niet abstract opgevat, maar in de betekenis van plaats van samenkomst op eenzelfde tijdstip van kooplustigen en aanbieders van waren".

Dit verschil in structuur meende Prof. Polak te moeten toeschrijven aan „de tendens, dat in het algemeen goederen, welker productie met toenemende kosten geschiedt op markten, beurzen of veilingen worden verhandeld, terwijl goederen, met afnemende kosten voortgebracht, in gesloten ruil tusschen een verkooper en een kooper worden omgezet". De producent, die onder stijgende kosten werkt, zal zijn aandacht concentreren op de te maken prijs, hij zal de openheid van de concrete markt begeren, de producent, die onder dalende kosten werkt, zal vooral uit zijn op omzetvergroting en zal streven naar een zo groot mogelijke geheimhouding. De agrarische en de extractieve productie hebben plaats onder stijgende, de industriële onder dalenden kosten. Agrarische producten en voortbrengselen van extractieve nijverheid bewegen zich derhalve over concrete markten, industriële artikelen daarentegen vermijden deze markten. Aldus de gedachtengang van Prof. Polak.

Deze theorie heeft vele jaren de gangbare opvattingen op het gebied van de "Organisatie en Techniek van de Handel" bepaald. Naarmate echter de theoretische economie evolueerde, vermocht deze theorie de jongere generatie minder te overtuigen. Het karakter van "Realtype" dat Prof. Polaks theorie droeg, sprak niet meer tot de generatie, die in formele theorieën werd opgevoed. De over-simplificatie, waaraan Prof. Polaks theorie op zekere punten leed, begon allengs meer duidelijk te worden.

In 1947 verscheen in De Economist een artikel van de hand van J. Zijlstra, thans hoogleraar aan de Vrije Universiteit, getiteld Markt- 
vorm, Kostenverloop en Structuur van de Handel, waarin een poging werd gedaan om de oude opvatting te corrigeren met behulp van de leer van de marktvormen.

In stede van de „realiteitstypering": de landbouw werkt onder stijgende, de industrie onder dalende kosten, stelde Zijlstra een formele theorie: Wie verkeert in een markt, getypeerd door volledig vrije mededinging, heeft geen reden tot productiebeperking beneden optimale grootte, en zal deswege altijd onder stijgende kosten werken. Deze formele theorie is zowel op de landbouw als op de industrie van toepassing.

Wanneer er sprake is van een zuig- dan wel van een persproces, waarmede men dan wil aangeven dat er concurrentie bestaat resp. tussen afnemers ter bemachtiging van het aanbod, en tussen aanbieders ter bemachtiging van de afzetmogelijkheid, dan wijst dat op en heeft het tot essentiële voorwaarde de afwezigheid van de marktvorm der vrije mededinging. Aldus kwam Zijlstra tot de conclusie: "Voor de structuur van de handel is doorslaggevend de marktvorm".

Twee wegen openen zich hier voor ons: de ene leidt tot een poging tot het leveren van een immanente critiek op Zijstra's betoog, welke weg ons zou voeren tot een nadere analyse van de begrippen zuigen persproces en in het algemeen tot een beoordeling van de bruikbaarheid der marginale analyse voor de oplossing van practische vraagstukken, de andere leidt tot een aanvulling van het betoog van Prof. Zijlstra met een beschouwing over het vraagstuk van het gebruiken of vermijden van de concrete markt, en tot een verzwak-

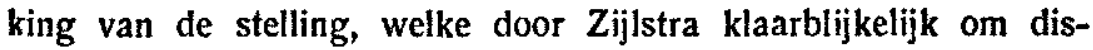
cussiedoeleinden is geaccentueerd, dat dé marktvorm doorslaggevend zou zijn voor dé structuur van dé handel.

Wij zullen hier aan deze tweede weg de voorkeur geven. Voor het ogenblik aanvaarden wij derhalve de uitspraken van Zijlstra t.a.v. het kostenverloop en t.a.v. het zuig- en persproces, doch wij gaan ons afvragen of de marktvorm ook geacht moet worden doorslaggevend te zijn t.a.v. de vraag of dan niet gebruik gemaakt wordt van de concrete markt ${ }^{5}$ ).

8) Ter voorkoming van misverstand zij uitdrukkelijk gesteld, dat Zijlstra weliswaar sprak van "de structuur van de handel", waaronder ook het door ons bedoelde vraagstuk te vatten ware, doch dat hij de quaestie van het al dan niet gebruiken van de concrete markt zelf niet expliciet aan de orde heeft gesteld. 
Alvorens ons aan de beantwoording van de gestelde vraag te zetten, moeten wij ons beraden op de functie, welke de marktvormen in de prijstheorie vervullen.

De prijstheorie beoogt gedachtengangen aan de hand te doen, welke bij de analyse van het economische proces van nut kunnen zijn. Ter formulering van deze gedachtengangen gaat $z i j$ uit van een vereenvoudigd maatschappijbeeld, de marktvorm.

Indien men dan onder structuur van de handel eenvoudig de structuur van het ruilverkeer verstaat, en de marktvorm met tal van bijzonderheden gaat aankleden, zal men bemerken, dat marktvorm en structuur van de handel identiek zijn. De marktvorm is dan niet doorslaggevend voor, doch hij is zelf de structuur van de handel.

Wil onze verhandeling dan nog zinvol zijn, dan moeten wij onderzoeken in hoeverre de schema's, welke aan de moderne prijstheorie ten grondslag liggen, de essentiële factoren bevatten, die het ontstaan van concrete markten veroorzaken en de gedaante er van bepalen.

De vraag, welke wij aan de orde stelden, is in wezen drieledig, t.w., om welke reden van concrete markten gebruik gemaakt wordt, door welke oorzaak het verschil in gedaante wordt te weeg gebracht, en door welke personen of instanties de organisatie in het leven wordt geroepen. In deze drie delen willen wij dan ook ons vraagstuk splitsen, en ons telkenmale afvragen, in hoeverre kennis van de marktvormen ons het rechte antwoord verschaft.

Bezien wij vooreerst de vraag naar het waarom. Verscholen tussen andere opmerkingen, en vaak minder opgemerkt dan de zinsnede verdient, staat in Prof. Polak's Taak van de Tusschenhandel als een belangrijk motief genoemd het gevoelen van onbehagen, dat ondoorzichtigheid van de marktverhoudingen bij marktpartijen oproept, waardoor deze de voorkeur gaan geven aan samenkomst, waarbij de geïsoleerde ruil zich oplost in een algemene ruil: „Van de oudste ruilingen af heeft men de gegadigden op markten bijeen verzameld, gedreven door de vrees, voor zijn goederen minder tegenwaarde terug te krijgen dan men er voor had kunnen bedingen" ${ }^{6}$ ).

In de recente publicatie van Prof. Haccoû Handel en Marktwezen in Goederen ${ }^{7}$ ) vindt men aan ditzelfde argument een aanzienlijke

6) Bedrijfseconomische Studiën, Haarlem 1932, blz. 327 .

7) J. F. Haccoû, Handel en Marktwezen in Goederen, Leiden 1948. 
plaats ingeruimd. Op blz. 376 bijv. lezen wij: „De concentratie en veralgemening van de ruil verbeteren voorts het inzicht van partifen in de kwalitatieve en kwantitatieve verhoudingen en dus in de marktsituatie... maken met andere woorden de verhoudingen van vraag en aanbod doorzichtiger en leiden tot een zuiverder prijsvorming". Op blz. 400, sprekende over de veilingen van groente en fruit zegt Haccoû: „Bij het bestaan van een geïsoleerde ruil zou de tuinder volkomen in het onzekere verkeren omtrent de juiste waarde van zijn product in het kader der bestaande verhoudingen en de koper zou de reeds bestaande psychologische druk nog belangrijk vergroten".

Laten wij een ogenblik blijven stilstaan bij het argument, dat de ondoorzichtigheid der marktverhoudingen het motief vormt tot het bezoeken van een concrete markt. Kan men dan zeggen, dat de marktvorm doorslaggevend is, en is het nuttig zulks te doen?

Men kan dit inderdaad zeggen, mits men de mate van doorzichtigheid als een kenmerk van de vermelde marktvorm aanneemt, doch het wezenlijke schuilt dan toch in een bijvoegelijk naamwoord, sc. "imperfect" dat aan verschillende zelfstandige naamwoorden kan zijn gekoppeld, waardoor licht verwarring optreedt en de aandacht van het essentiële eer wordt afgeleid dan er op geconcentreerd.

Aangezien de economische wetenschap uiteindelijk de instrumenten voor de economische politiek moet verschaffen, in het onderhavige geval dus inzicht moet geven over de wenselijkheid of noodzakelijkheid van vestiging, handhaving, wijziging of opheffing van het instituut der concrete markt, moet naar het ons voorkomt, de aandacht geconcentreerd worden op de belangrijkheid van de ondoorzichtigheid der marktverhoudingen, en de belangrijkheid hiervan eenmaal aanvaard op de krachten, welke die ondoorzichtigheid veroorzaken.

Zou men zich willen stellen op het standpunt van de „reine Wissenschaft" en louter uit wetenschappelijke belangstelling vragen naar de factor, die doorslaggevend is voor het al dan niet gebruiken van de concrete markt, dan dringt men toch dieper door in de keten van oorzaak en gevolg door de krachten, welke de ondoorzichtigheid veroorzaken, als doorslaggevend aan te merken dan het ondoorzichtige marktbeeld zelf.

$\mathrm{Er}$ is evenwel nog een tweede argument, dat wordt aangevoerd ter verklaring van de concrete marktvorming. Zowel door Polak als door Haccoû wordt nl. gewezen op kostenbesparingen, welke in 
concentratie der ruilende partijen kunnen zijn opgesloten en een motief kunnen vormen tot het bezoeken van de concrete markt ${ }^{8}$ ). Onder een en dezelfde marktvorm, zeg die van de vrije mededinging zal men dan in het ene geval wel, in het andere geen gebruik maken van de concrete markt. Voor zo ver dit argument geldt, kan men dan toch bezwaarlijk volhouden, dat het de marktvorm is, die tot concrete marktvorming aanleiding geeft ... Zijlstra's stelling, toegepast op de onderhavige questie, ondergaat daarmede de verzwakking, welke wij eerder aankondigden.

De vraag naar de oorzaak van het verschil in gedaante roept nu om beantwoording. Hierbij moeten wij voor ogen houden, dat de organisatie van een concrete markt weliswaar die elementen van differentiatie van de waar, welke uit onwetendheid omtrent de marktverhoudingen voortvloeien, zal opheffen, doch die differentiatie van de waar, die in dieper gelegen opvattingen bij het publiek is verankerd, zal laten voortbestaan.

Wij willen nu een ogenblik veronderstellen, dat het streven naar welvaart de massa der individuen voldoende organisatievermogen verschaft om die organisatievormen in het leven te roepen, die bij de heersende marktvorm het beste aansluiten.

Wanneer men de zaak zo stelt, heeft men tegelijkertijd gezegd, dat de gedaante van de concrete markt wordt bepaald door de marktvorm nadat daaruit het element imperfectie, voor zo ver veroorzaakt door ondoorzichtigheid der marktverhoudingen, is verwijderd. Bij vrije mededinging, met zijn grote aantallen marktpartijen en zijn homogene waar hoort dan de hoog ontwikkelde beurs, waar op type en standaardcontract wordt gehandhaafd. Bij polypolie, met zijn grote aantallen marktpartijen en zijn gedifferentiëerde waar, hoort het marktplein en de lager georganiseerde beurs waar de handel na bezichtiging van partij of van monster geschiedt. Bij zekere graad van monopolie past de veiling en de inschrijving ${ }^{9}$ ).

8) Wij denken hierbij aan Polaks Gelijkmatigheidstendens, in de Amsterdamse terminologie aan het diversiteitsverschijnsel. Polak's argument van het werken op grotere schaal, i.c. door het marktapparaat, willen wij hier buiten beschouwing laten, aangezien men zou kunnen stellen, dat "free entry", als kenmerk van een volkomen markt, een dermate grote deelbaarheid van productiefactoren veronderstelt, dat dit element niet in het geding kan treden.

9) Dit laatste punt behoeft wellicht enige toelichting, welke wij dan hier willen geven. Het wezenlijke van de veiling is, dat er slechts éen aanbieder is, die de uit meerdere personen bestaande wederpartij noopt tot het uitspreken van een waardering. Het oogmerk is daarbij de hoogst mogelijke 
Als derde moet nu de vraag beantwoord worden door welke personen of instanties de concrete markt wordt tot stand gebracht.

Men zal toch moeten toegeven, dat zeer wel bij marktpartijen het verlangen naar een betere positie in de markt kan leven en dat, wanneer aan dit verlangen wordt voldaan zekere marktorganisatie i.c. de concrete markt wordt geschapen, doch dat dit verlangen nooit tot bedoeld resultaat voert als gevolg van het ontbreken van het vereiste organisatievermogen.

Soms wordt de organisatie van de concrete markt door de overheid bewerkstelligd, soms door een speculatief orgaan, vaak door een organisatie van belanghebbende tussenpersonen of handelaars. In andere gevallen, wij denken aan het coöperatief veilingwezen, is het de stuwende kracht van een of weinige eminente persoonlijkheden.

Ook het optreden van de hier bedoelde personen kan men doorslaggevend noemen voor de structuur van de handel. Kennis van de marktvorm brengt ons echter op dit punt niet verder, aangezien in de marktvorm toch niet wordt opgenomen hoe het met het organiserend vermogen der personen is gesteld.

Wanneer men dan de structuur van de handel tracht te verklaren,

waardering te krijgen. Dit spel zou niet te spelen zijn, indien er tegetijkertijd meer aanbieders in de markt waren. Vandaar, dat wij spreken van monopolie.

$\mathrm{Nu}_{\mathrm{u}}$ is verder de vraag, wat men wil verstaan onder de markt. In laatste instantie concurreren alle goederen met elkaar, en vormen dus een samenhangende markt. Van monopolie spreekt men echter als de uitwijkbeweging bezwaarlijk is wegens het ontbreken van nabije vervangingsmogeljjkheden. Dit is een quaestie van gradatie, vandaar onze omschrijving monopoliegraad.

De hier bedoelde "monopoliepositie" kan tot grondslag hebben aanmerkelijke verschillen in de geaardheid van het goed, gelijk bij kunstyoorwerpen, zekere qualiteiten thee en tabak het geval kan zijn, zij kan ook berusten op het marktscheidende element van afstand en tijd. Dit laatste zien wij bij de veilingen voor groenten en fruit. Verschillen in geaardheid van het goed, dat door de afzonderlijke kwekers wordt aangeboden, zijn daarbij weliswaar niet geheel afwezig, doch van veel groter belang is o.i. het feit, dat op moment $x$ in plaats $y$ slechts één aanbieder in de markt is, waardoor de gegadigde slechts als alternatief heeft of telefonisch in een andere markt te mijnen, dan wel een ander tijdstip af te wachten, waarvan hij de dan heersende kooplust niet kent. Deze grondslag wordt gevormd vooreerst door de afspraak der aanbieders, inhoudende dat op ieder tijdstip slechts één verkoper in de markt zal zijn, en de bederfelijkheid van de waar, waardoor goederen, die eenmaal in handen van een koper zijn overgegaan, in het algemeen snel naar het afzetgebied moeten worden geëxpedieerd en geringe kans maken op de banken van de veiling andermaal van eigenaar te veranderen. Daardoor immers zou de veiling ontaarden in een beurs. 
en zeker wanneer men daarin betrekt vraagstukken zoals door ons hier aan de orde gesteld, waarbij het gaat over instituten, zal men een veelheid van omstandigheden en factoren zowel van sociologische, juridische, psychologische als van economische aard in zijn beschouwing moeten betrekken.

Naast het marktwezen was het het vraagstuk van de hoge kosten van de distributie, waarover wij heden tot $U$ wilden spreken. Gelijk gezegd zouden wij daarbij onze gedachten bepalen tot de detailhandel in groenten en fruit.

Niet zo lang geleden deed zich in Limburg een conflict voor tussen de handelaren in groente en fruit en de Katholieke Arbeidersbeweging, waarbij deze laatste, met behulp van een grote verbruikscoöperatie, die een vergunning bezit om handel te drijven in groente en fruit, een poging deed om het publiek tegen lage prijs fruit ter beschikking te stellen. De aanvoeren op de veilingen waren in die tijd overvloedig, de veilingprijzen laag, doch de detailhandelsprijzen desondanks hoog, als gevolg van de naar het oordeel der K.A.B. te hoge handelsmarges. Dit conflict vestigde de aandacht op de reeds door velen geuite klacht van de hoge kosten der distributie.

Het zou mij te ver voeren, het vraagstuk van de distributiekosten in deze branche op enigermate uitputtende wijze te behandelen. Ik wil mij dan ook beperken, en wel, waar deze verhandeling gewijd is aan enige toepassingen van de leer van de marktvormen, tot het organiserende en selecterende vermogen van de vrijheid tot concurreren, in een markt, welke geen vrije mededinging in de theoretische zin kent.

Concurrentie, het woord en het beeld wekt de indruk ontleend te zijn aan de wedrennen van het oude Rome. Het wijst op het streven i.c. van de ondernemer, door welke beweegredenen dan ook ingegeven, om anderen voor te zijn, te overtroeven; het wijst tevens op het meelopen door anderen achter de gangmaker aan. Willen wij de beeldspraak volhouden, dan moeten wij ook bedenken, dat in vele gevallen het aantal courreurs niet bepaald is, doch dat de mogelijkheid om de baan te betreden voor outsiders openstaat.

Laten wij dan eerst eens trachten vast te stellen, welke marktvorm praevaleert in de detailhandel voor groente en fruit. Een deel van de verkoop geschiedt in de winkels aan vaste en zogenaamde loopklanten, een ander deel wordt „aan de kar" door vaste klanten 
gekocht. Daarnaast bestaan er venters, - wel te onderscheiden van de groenteman, die met $z$ ijn voertuig zijn vaste klanten bezoekt -, die bijv. met fruit de straten door trekkend aan gelegenheidskopers hun waren afzetten. De waar, welke door de onderscheidene aanbieders op de markt wordt gebracht, leent zich moeilijk voor een nauwgezette prijsvergelijking. Kleine prijsverschillen worden dan ook niet opgemerkt, of zo zij al worden opgemerkt, vormen zij veelal toch geen motief om van leverancier te veranderen.

Het moge duidelijk zijn, dat deze betrekkelijke prijsongevoeligheid bij diegenen, die van nature of doelmatigheidshalve een vasteklant-relatie tot een leverancier onderhouden, veel sterker is dan bij de zogenaamde loopklanten. Ook bij deze laatste groep echter is de geringe prijsgevoeligheid niet te ontkennen.

Deze prijsongevoeligheid is, gelijk wij zeiden, betrekkelijk. Grote prijsverschillen hebben onmiskenbaar invloed, doen ontegenzeggelijk uitwijkbewegingen naar andere leveranciers optreden. Het komt ons daarbij voor, dat in deze prijsverschillen zekere drempels aanwezig zijn waar de elesticiteit plotseling aanzienlijk verandert.

Hieruit menen wij de prijspolitiek in deze branche te kunnen verklaren. Het algemeen prijsniveau van groente en fruit fluctueert in die mate, dat het in iedere tijdseenheid op de veilingen aangevoerde quantum, voor zo ver het aanbod hiervan niet door autoriteiten wordt opgehouden, door de markt wordt opgenomen. Zouden immers, in tijden van overvloedige aanvoeren, de winkeliers (en de daarmede gelijk te stellen de hun klanten bezoekende groentenmannen) de prijzen van een voorafgaande periode van kleinere aanvoeren hạdhaven, dan zou een deel van de aanvoer op de veiling dreigen onverkocht te blijven. Dit deel zou dan worden opgenomen door de eigenlijke venters, die tegen veel lagere prijzen verkopend de deelmarkten der gevestigde detaillisten zouden doorbreken.

Het bijzondere prijsniveau, t.w. de handelsmarge, zal echter niet, of althans in veel geringere mate deze fluctuaties doormaken, aangezien een manipulatie hierin weliswaar tot een andere spreiding van de koopkrachtsstroom zou leiden, doch niet tot een omzetvergroting van enige betekenis voor de afzonderlijke aanbieder.

Wie vertrouwd is met de economische literatuur zal in deze situatie de marktvorm onderkennen, welke door Chamberlin als monopolistische concurrentie voor de grote groep van aanbieders, en door Triffin als "atomistic heteropoly" is gekenmerkt.

Terloops zij opgemerkt, dat geenszins alle detailhandelsmarkten 
zich door deze marktvorm kenmerken. Bij brood en melk bijv. is door de veel grotere vergelijkingsmogelijkheid de prijsgevoeligheid van de vraag veel groter. Prijsveranderingen, doorgevoerd door een afzonderlijke aanbieder, brengen daar dan ook veel grotere uitwijkbewegingen van de ene leverancier naar de andere te weeg, welke uitwijkbewegingen zo geconcentreerd liggen op weinige andere aanbieders, dat represailles niet uitblijven. De relevante marktvorm is in deze gevallen die van het oligopolie, met zijn bekende prijslabiliteit. Brood- en melkoorlogen zijn dan ook zeer wel bekend, doch wie hoorde ooit van bloemkool- of kropsla-oorlogen! Prijsoorlogen kunnen evenwel niet eindeloos duren, $\mathrm{en}$ is de vrede eenmaal weergekeerd, dan heeft de herinnering van de geleden schade en schande vaak ten gevolge, dat de aanbieders zich verder (zolang de schrik nog in de benen zit) van prijsmanipulatie onthouden.

Is dit eenmaal bereikt, dan voltrekt het concurrentieproces zich verder grotendeels volgens dezelfde lijnen als in die markten, waar de prijsgevoeligheid gering is.

Concludeert de theorie voor de marktvorm der vrije mededinging nog, $z \mathrm{ij}$ het onder vrij onereuze veronderstellingen, tot een optimale combinatie van productiefactoren, voor de monopolistische marktvorm stelt $\mathrm{zij}$, onder de vrij reëele veronderstelling van het streven naar maximale winst, de onvermijdelijkheid van beperking van het aanbod tot minder dan optimale grootte, of, zo dit al toevalligerwijze mocht worden bereikt, tot verkoopprijzen, welke de kostprijzen te boven gaan.

Men zou, gelijk Hayek doet, de moderne theorie kunnen tegenwerpen, dat zij teveel haar ogen sluit voor de gunstige invloed, welke de concurrentie op de efficiency, dus op de hoogte der kostenlijnen, uitoefent. Het ligt nu allerminst in onze bedoeling deze mogelijke gunstige invloed te ontkennen. In die marktomstandigheden, waarin prijsmanipulatie een effectloos of een te gevaarlijk middel is gebleken, openbaart de concurrentie zich aldra in andere vormen, zeggen wij in een verhoging van het dienstbetoon, zulks in de ruimste zin des woords. Dit dienstbetoon is allerminst zonder invloed op de hoogte van de kostenlijnen. De winkelier, die zijn winkel verfraait om klanten te winnen en/of te behouden, zal er ook op attent zijn, dat zijn waar in goede hoedanigheid verkeert; hij zal zijn outillage dan ook zodanig kiezen, dat de kansen op bederf verkleind worden. In dit laatste ligt een element besloten, dat de kostenlijnen naar beneden kan brengen. Deze tendens kan echter zeer wel, 
en zal ook vaak worden overgecompenseerd door een kostenverhogende tendens, eveneens besloten in de service-concurrentie, men denke b.v. aan de uitbreiding van het assortiment, waardoor omzetsnelheid af- en kans op bederf toeneemt, aan bezorgdiensten, aan het accepteren van iedere bereikbare klant, ook al woont hij verre buiten de normale bestelroutes.

Wanneer wij hier spreken over een kostenverhogende tendens, dan hebben wij nog niet de kosten per eenheid van omzet op het oog, doch voorlopig uitsluitend de hoogte van de kostenlijnen. Hoe dit spel van krachten zal uitvallen voor de kostprijs per eenheid, hangt af van de verandering, welke in de omzet wordt te weeg gebracht. Concurreren ongeveer even krachtige bedrijven met elkaar, dan is enige wijziging in de omzetverhoudingen ter nauwernood te verwachten, en is het vermoedelijke gevolg slechts een ondermijning van elks rendabiliteit. Vindt de concurrentie haar oorsprong in, of valt zij samen met een krachtige toevloed van nieuwe bedrijven tot deze bedrijfstak, dan kan men slechts verwachten, dat voor het merendeel der bedrijven de afzetmogelijkheden geringer worden, terwijl daartegenover de kostenlijnen stijgen, en het raakpunt tussen afzet- of vraagcurve en kostencurve, d.w.z. het punt, waar geen winst meer wordt gemaakt, spoedig zal zal bereikt.

Die vestigingsactiviteit zelf vindt haar oorsprong in een afwijking tussen wat de nieuwelingen als verwacht inkomen in deze branche zien en datgene, wat zij zouden kunnen verdienen indien $z i j$ in andere werkzaamheid bleven, dan wel een andere werkzaamheid kozen, verminderd met c.q. vermeerderd met zekere premie voor hun afkeer van dan wel voorkeur voor bovenbedoelde andere werkzaamheid. Eleganter geformuleerd luidt dit: wanneer de verwachte inkomensverhouding afwijkt van de marginale substitutieverhouding tussen deze branche en andere aanwendingen van arbeid, zal zich vestigingsactiviteit voordoen.

Wanneer, zoals in de groente- en fruithandel naar wij menen het geval is bij outsiders de opvatting heerst, dat de benodigde vakbekwaamheid gering is, en wanneer huisvesting en kapitaalvoorziening geen ernstige moeilijkheden baren, en er geen wettelijke belemmeringen bestaan zal de vestigingsactiviteit doorgaan tot zeker evenwicht wordt bereikt tussen het verwachte inkomen en het inkomen van vrij weinig geschoolde arbeid. In tijden van werkloosheid zal dit een evenwicht zijn tussen de verwachte inkomens en de werkloosheidsondersteuning. 
Dit evenwicht is geen gelijkheid. Is er een sterke voorkeur voor - zelfstandigheid, resp. een hevige afkeer tegen werkloosheid, dan kan het verwachte inkomen zeer wel beneden het loon resp. de werkloosheidsuitkering liggen.

Dit evenwicht is voorts slechts een ex ante evenwicht, d.w.z. een evenwicht tussen verwachte grootheden. Allerminst is beweerd, dat dit evenwicht zich ook als werkelijke inkomensverhouding zal voordoen. De verwachting omtrent het te behalen inkomen wordt immers niet ingegeven door een inzicht in de toekomstige marktverhoudingen, doch berust op allerlei vage indivicaties, zoals de breedte van de handelsmarges, de reputatie van welvarendheid, welke menige branche uit vroegere jaren nog meedraagt. Wordt de verwachting niet vervuld, dan betekent dat nog niet, dat men terugkeert op zijn weg. De substitutieverhouding is namelijk voor de heenweg een geheel andere dan voor de terugweg. De benadering van een werkelijk evenwicht kan dan ook zeer lang op zich laten wachten.

Het organiserend vermogen van de concurrentie in vrijheid is in deze omstandigheden uiterst gebrekkig. Ondanks het ontbreken van naar maatstaven van normaal ondernemersinkomen berekende winst, ja zelfs wanneer het economisch resultaat in menig bedrijf negatief is, is de distributie duur door te kleine omzetten per bedrijf, te groot dienstbetoon, te geringe efficiency, en dragen de consument en de producent daarvan mede de lasten.

Ook het selecterend vermogen der concurrentie in vrijheid is in dit type branches gering. Terwijl men voor een markt met volledig vrije mededinging on the long run nog mag verwachten, dat de aanbieders, die efficiëntere methodes weten te ontwikkelen, door hun productievergroting geleidelijk aan de marktprijs doen dalen, waardoor deze voor de minder efficiënte geen lonende productie meer mogelijk maakt, zou in de marktomstandigheden van het "atomistic heteropoly" de bate door hogere efficiëncy behaald aangewend moeten worden ter beïnvloeding van de vráag, en op deze wijze de minder efficiënte uit de markt gedrongen moeten worden.

Gezien de grilligheid van de reacties van het publiek mag men echter allerminst met zekerheid verwachten, dat dit uitdrijvingsproces zich zal voordoen.

Wij maakten in het bovenstaande gebruik van gedachtengangen, zoals zij door Chamberlin, Mrs Robinson, Triffin en anderen zijn 
ontwikkeld. Wij kozen daarbij op tal van punten reeds reëlere veronderstellingen, gelijk overigens ook door een auteur als $\mathrm{H}$. Smith, Retail Distribution, wordt gedaan, dan die welke ten grondslag liggen aan de theoretische stelsels der bovenbedoelde auteurs.

De leer van de marktvormen en van de daarop gebouwde prijstheorieën is ongetwijfeld een belangrijke aanwinst voor de economische wetenschap. Dat zij echter nog op vele punten op reëlere veronderstellingen gebaseerde uitwerking behoeft, zal wel weinig in twijfel getrokken worden.

\section{Mijne Heren Curatoren,}

Het is mij een behoefte $U$ dank te zeggen voor het feit, dat gij mij bij H. M. de Koningin hebt willen voordragen. Daar het getal mijner levensjaren nog, betrekkelijk, gering is, hield het feit van mijn voordracht noodzakelijkerwijze een groot element van crediet in. Wie crediet ontvangt, zal dit met interest moeten terug betalen. Ik moge $U$ verzekeren van mijn oprechte wil om een goede debiteur te zijn.

\section{Mijne Heren Hoogleraren,}

Ook $\mathrm{Gij}$ hebt medegewerkt tot mijn benoeming, en ook $\mathrm{U}$ dank ik voor het in mij gestelde vertrouwen. Ik dank $U$ voorts voor de welwillendheid, waarmede Gij mij in Uw midden hebt opgenomen. Van mijn wil tot een aangename samenwerking met $U$ moge ik hier getuigen.

Hooggeleerde Minderhoud, Horring, Hofstee, Slicher van Bath, de Vries en Polak.

De Landbouwhogeschool mag zich, in de sector der economische en sociale wetenschappen, verheugen op een bezetting, welke naar qualiteit en quantiteit tot eer van menige economische faculteit of Hogeschool zou strekken. Met vreugde heb ik dit geconstaeerd. Het biedt mij de onschatbare gelegenheid zowel in de docerende als in de wetenschappelijke taak, welke mij wacht, te steunen op Uw rijke en rijpe ervaring.

Bijzonder intensief en verkwikkend is, in de afgelopen maanden, waarin ik reeds aan deze Hogeschool mijn werkzaamheden heb verricht, het contact geweest met $U$, Hooggeachte Polak, van wien ik een deel Uwer taak heb mogen overnemen. Al zijn in ons land rechtswetenschap en economische wetenschap zeer van elkaar vervreemd, in $U$ heb ik een man mogen ontmoeten, die niet alleen grote belang- 
stelling voor de economie aan de dag legt, doch ook in ruime mate inzicht en kennis van deze wetenschap blijkt te bezitten. Ik hoop op een voortduren van de gedachtenwisselingen, welke wij reeds meermalen hadden, en voor mij zeer vruchtbaar bleken.

Mijne Heren Hoogleraren en Lectoren der Ned. Econ. Hogeschool.

Vier jaren heb ik als lector in Uw midden mogen verkeren, jaren, welke voor mij van grote betekenis zijn geweest. Ik dank $U$ voor de vriendschap, welke ik in deze tijd van $U$ heb mogen ondervinden.

Op dit moment gaan mijn gedachten uit naar diegenen, die eens mijn leermeesters waren. Slechts weinigen van hen zijn aan de mij zo vertrouwde Rotterdamse Hogeschool nog verbonden. In eerbied wil ik gedenken Prof. Dr N. J. Polak, die zo ontijdig en onverwacht aan de Rotterdamse gemeenschap moest ontvallen, en wien ik grote dank verschuldigd ben.

Dank ook wil ik betuigen aan $U$, Hooggeleerde de Vries voor de opleiding welke ik voor een groot deel van $U$ ontving en voor de vriendschap welke ik van $U$ mocht ondervinden.

- Dat Gij op deze dag de reis naar Wageningen hebt ondernomen, vervuld mij met grote vreugde.

Talrijk zijn reeds diegene Uwer leerlingen, die her en der in den lande tot economische leerstoelen werden beroepen. Dat zulks ook het geval is aan de Landbouwhogeschool, nu hier de economische rector tot expansie is gekomen, moet $\mathrm{U}$ wel voldoening schenken.

Moge Uw voorbeeld mij leiden bij de taak, die mij hier wacht.

\section{Dames en Heren Studenten.}

Het Hoger Onderwijs vormt een symbiose van wetenschapsbeoefening en onderwijs. Het is daarbij niet slechts zo, dat in de docerende taak de resultaten van het wetenschapplijk werk worden geopenbaard, het wetenschappelijk werk zelf ondergaat de bevruchting van de gedachten, die docerende opkomen. Wil deze bevruchting haar volle omvang bereiken, dan is daarvoor een actieve medewerking van de zijde der studenten nodig.

Gij studenten, moet dan meedenken, meeleven, meespelen. Het heeft mij zeer verheugd bij $U$ die belangstelling en dat mede spelen te hebben aangetroffen.

Ik heb gezegd. 